\title{
Modeling the chemical dynamics of chloride ion indicators
}

\author{
Alexander J Redford ${ }^{1 *}$, Susan Ingram², Alexander Dimitrov ${ }^{1}$ \\ From Twenty First Annual Computational Neuroscience Meeting: CNS*2012 \\ Decatur, GA, USA. 21-26 July 2012
}

Fluorescent indicators have shown promise as a relatively non-invasive probe to measure cytosolic ion concentrations in brain slices and neuron cultures using microscopy imaging. Most fluorescent ion indicators bind selectively with a certain ion in solution causing a decrease in fluorescence in a process known as quenching. Under steady state conditions, a fluorescence measurement, made at a specific point and time, is directly related to the local ion concentration at the same point and time, typically via the Stern-Volmer relationship. However, this is usually no longer true under the dynamic conditions inside a cell when transmembrane currents are active.

In our research, we are interested in measuring chloride $\left(\mathrm{Cl}^{-}\right)$channel currents because of their implication in substance abuse mechanisms. Useful probes have been found in $\mathrm{Cl}^{-}$sensitive dyes, such as $\mathrm{N}$-(6methoxyquinolyl) acetoethyl ester (MQAE) [1], and 6-methoxy- $N$-ethylquinolinium (MEQ) [3], and variants of the Yellow Fluorescent Protein (YFP) useful as a $\mathrm{Cl}^{-}$biosensor in dendritic compartments [4].

We have modeled jointly the $\mathrm{Cl}^{-}$flow as part of a Hodgkin-Huxley type model and the interaction of $\mathrm{Cl}^{-}$ with a generic binding indicator as a system of non-linear differential equations derived from biophysical and chemical kinetic theory, using arbitrary parameters. Using the quenched indicator concentration as the given input signal, several approximate solutions can be derived for the corresponding output signal, the $\mathrm{Cl}^{-}$current of interest. To date, we have explored a simple quasi-linear approximation similar to that discussed in [2], as well as a best-fit model-based approximation in which the output is assumed to satisfy a sum of parameterized exponential curves (an assumption consistent

\footnotetext{
* Correspondence: aj.redford@wsu.edu

'Department of Mathematics, Washington State University, Vancouver WA 98686, USA

Full list of author information is available at the end of the article
}

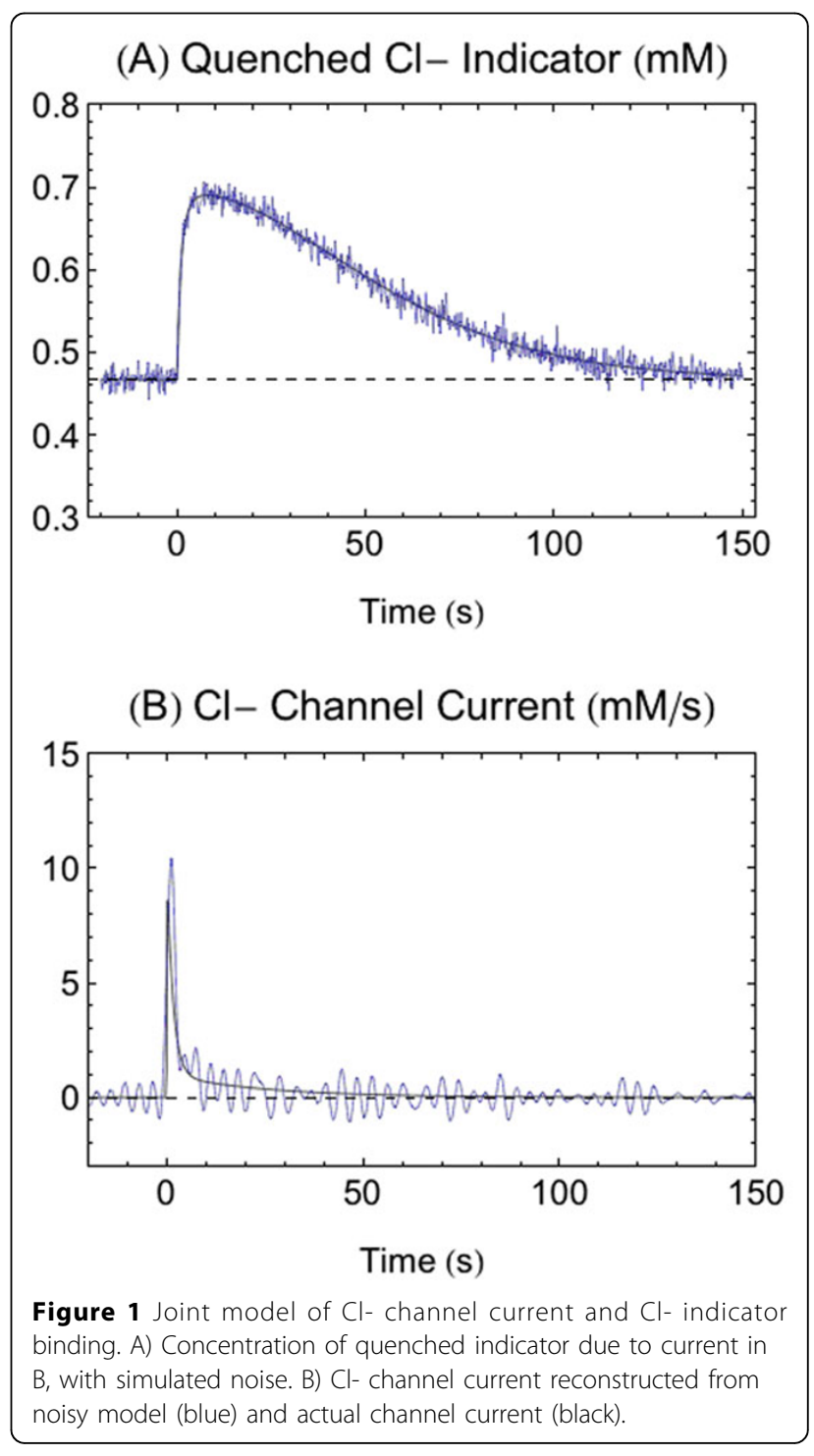

C 2012 Redford et al; licensee BioMed Central Ltd. This is an Open Access article distributed under the terms of the Creative Commons 
with the theory of neuron excitation). We consider how both approximations can be optimally applied to a noisy input signal, and on their limitations in probing disparate time scales and small currents. We also test these methods on current experimental data obtained as part of study of the biophysics of drug addiction (Ingram et. al, in progress).

\section{Author details}

'Department of Mathematics, Washington State University, Vancouver WA 98686, USA. ${ }^{2}$ Department of Neurological Surgery, Oregon Health \& Science University, Portland OR 97239, USA.

Published: 16 July 2012

\section{References}

1. Marandi N, Konnerth A, Garaschuk O: Two-photon chloride imaging in neurons of brain slices. Pflugers Arch - Eur J of Physiol 2002, 445:357-365.

2. Borst $A$, Abarbanel HDI: Relating a calcium indicator signal to the unperturbed calcium concentration time-course. Theor Biol Med Model 2007, 4:7.

3. Inglefield JR, Schwartz-Bloom RD: Fluorescence imaging of changes in intracellular chloride in living brain slices. Methods 1999, 18(2):197-203.

4. Waseem T, Mukhtarov M, Buldakova S, Medina I, Bregestovski P: Genetically encoded $\mathrm{Cl}$-Sensor as a tool for monitoring of $\mathrm{Cl}$-dependent processes in small neuronal compartments. J Neurosci Methods 2010, 193(1):14-23.

\section{Submit your next manuscript to BioMed Central} and take full advantage of:

- Convenient online submission

- Thorough peer review

- No space constraints or color figure charges

- Immediate publication on acceptance

- Inclusion in PubMed, CAS, Scopus and Google Scholar

- Research which is freely available for redistribution

Submit your manuscript at www.biomedcentral.com/submit 